\title{
Response to Callus Induction and Regeneration of Newly Released BRRI Rice Varieties
}

\author{
S D Joya ${ }^{1 *}$, S Sultana ${ }^{1}$, J Ferdous ${ }^{1}$, M A Qayum ${ }^{2}$ and M E Hoque ${ }^{1}$
}

\begin{abstract}
A study was carried out for developing an efficient callus induction and regeneration system for three newly developed BRRI varieties namely BRRI dhan86, BRRI dhan87 and BRRI dhan89. Dehusked seeds were plated onto MS and N6 media with two hormone combinations for callus induction. Calli obtained from each callus induction medium were transferred to four different regeneration media. Callus induction frequency and regeneration ability were significantly influenced by rice varieties, and interactions of variety and media. Among the media compositions, the highest callus (59.44\%) were obtained from $\mathrm{C}_{1}$ (MS+2mg/1 2,4-D) followed by $\mathrm{C}_{2}$ ( MS+2 mg/1 2,4-D+0.5 mg/l kinetin), $C_{3}$ ( N6+2 mg/1 2,4-D) and $\mathrm{C}_{4}$ (N6+2 mg/l 2,4-D+0.5 mg/l kinetin) medium. The highest regeneration $\left(45.74 \%\right.$ ) was obtained from $R_{2}(M S+4 \mathrm{mg} / \mathrm{ml} \mathrm{BAP}+1.2 \mathrm{mg} / \mathrm{ml}$ kinetin $+0.5 \mathrm{mg} / \mathrm{ml} \mathrm{NAA})$, followed by $\mathrm{R}_{3}(1 \mathrm{mg} / \mathrm{ml} \mathrm{BAP}+1 \mathrm{mg} / \mathrm{ml}$ Kinetin $+1 \mathrm{mg} / \mathrm{ml} \mathrm{NAA}), \mathrm{R}_{4}(2$ $\mathrm{mg} / \mathrm{ml}$ kinetin $+1 \mathrm{mg} / \mathrm{ml} \mathrm{NAA}+300 \mathrm{mg}$ casein hydrolysate $)$ and $\mathrm{R}_{1}(2 \mathrm{mg} / \mathrm{ml} \mathrm{BAP}+1 \mathrm{mg} / \mathrm{ml}$ kinetin $+1 \mathrm{mg} / \mathrm{ml}$ NAA). BRRI dhan 86 showed the highest regeneration ability $(53.06 \%)$ than the other two varieties. It is observed that all varieties performed better in $C_{1}$ medium for callus induction and $\mathrm{R}_{2}$ medium for regeneration. This study also revealed that BRRI dhan86 was more responsive to callus induction and regeneration of green plants than the other two varieties.
\end{abstract}

Key words: Rice, callus, regeneration, hormone

\section{INTRODUCTION}

Rice is consumed as a staple food by more than half of the world population. Asia produces $90 \%$ of rice to meet up the demand (Bandumula et al., 2017). But rice production faces a threat of biotic (diseases and insects) and abiotic (salinity, drought, submergence, cold, heat) stresses due to rapid climatic changes (Das et al., 2019). Various research approaches like conventional breeding, somaclonal variation and marker assisted selection are being carried out since the last decades to develop tolerant rice varieties to reduce above mentioned stresses. Though some remarkable progresses are achieved, those are not worthy of satisfaction. Rice has become the prime target for genetic manipulations due to much dependence upon it as a staple food. Genetic transformation is an important biotechnological tool for developing stress tolerant rice varieties. However, the success of genetic transformation depends on several factors like genotype, media, light, hormonal effect, etc. Agrobacterium mediated transformation of rice requires an efficient regeneration system from a transformed callus and ironically, shoot regeneration represents a major bottleneck in this endeavour (Lim et al., 2017). Most of the indica rice genotypes, the world's most cultivated rice types, still remain less amenable to genetic transformation due to their poor regeneration potentiality (Sripriya $e t$ al., 2017). Although reporting is abundant on callus induction, regeneration and also transformation in japonica rice but it is limited in indica rice. In this context, the evaluation of new factors and their manipulation for efficient callusing and green plant regeneration from the mature embryo in indica

1Biotechnology Division, ${ }^{2}$ Agricultural Statistics Division, Bangladesh Rice Research Institute, Gazipur 1701. *Corresponding Author: shampanjoya@gmail.com 
rice is still challenging (Pawar et al., 2015). Researchers still struggle to optimize the callus induction procedures and efficiency of plant regeneration for rice mature embryos because it varies with variety to variety. In this context, the evaluation of varieties with different types of media and their manipulation for efficient callusing and green plant regeneration from the dehusked mature embryo in indica is still a challenging field (Pazuki and Sohani, 2013). Many studies have been conducted to optimize the techniques and composition of culture medium for callus induction from dehusked rice seed for various purposes (Benlioglu et al., 2015). However, it's application is still limited by many factors influencing the culture efficiency such as medium composition explants source (Din et al., 2016), genotype and environment (Islam et al., 2014). Among them, the genotype and nutrient composition are considered to be the major sources of variation for in vitro culture (Kido et al., 2015). For carrying out successful genetic transformation in rice, identification and screening of useful cultivars and the establishment of efficient regeneration protocols are very essential (Vennapusa et al., 2015). With the concern of the above situations, the present study was carried out to compare the performance of three newly developed high yielding rice varieties to find out the best combination of callus induction media and regeneration media for each variety and to identify the best responsive variety among them for transformation study.

\section{MATERIALS AND METHODS}

This research work was conducted at the Biotechnology Division of BRRI following Complete randomized design with three replications. A total of 1200 dry seeds of each three rice cultivars viz BRRI dhan86, BRRI dhan87, BRRI dhan89 were used for this study. Sterilization was carried out in a laminar air flow cabinet. Dehusked seeds were first sterilized with $70 \%$ ethanol for one minute followed by washing with sterile water. Then it was sterilized with $50 \%$ sodium hypochlorite $(\mathrm{v} / \mathrm{v})$ containing one drop of 20 for 40 minutes with gentle agitation. Seeds were thoroughly washed five to six times with sterile distilled water to remove sodium hypochlorite. The sterilized seeds were finally placed on sterile filter papers also to remove excess water.

Both MS (Murashige and Skoog, 1962) and N6 (Nitsch and Nitsch, 1969) basal salts were used to supplement with two different hormone combinations for calli induction (Table 1). Sucrose $30 \mathrm{~g} / 1$ and phytagel $4 \mathrm{~g} / 1$ was used as a source of carbohydrate and solidifying agent, respectively. Four types of media $\left(C_{1}, C_{2}, C_{3}\right.$ and $\left.C_{4}\right)$ were used. The $\mathrm{pH}$ of the media was adjusted to 5.8. The media was autoclaved at 15 psi at $121^{\circ} \mathrm{C}$ for 20 minutes. Four hundred sterilized seeds of each variety were placed on four callus induction media.

Then all culture plates were placed at $25 \pm 1^{\circ} \mathrm{C}$ under the dark condition for callusing. Data on \% callus induction and size of callus were collected after 21 days and 30 days after plating the seeds. Three week's old calli were transferred onto magenta boxes containing regeneration media. Callus obtained from each combination of callus induction media $\left(C_{1}, C_{2}\right.$, $C_{3}$ and $C_{4}$ were transferred onto four types of regeneration media $\left(R_{1}, R_{2}, R_{3}\right.$ and $R_{4}$ ) (Table 2). Regeneration efficiency was observed on MS media supplemented with four different combinations of naphthalene acetic acid (NAA), Kinetin (Kn) and 6-benzylaminopurine (BAP). The $\mathrm{pH}$ of the regeneration media was adjusted to 5.8. Cultural conditions of the study was maintained at $25 \pm 1^{\circ} \mathrm{C}$, light and dark cycle of 16:8 hours. After 30 days, \% regenerated calli and number of regenerated green plants were recorded. 
The data were subjected to ANOVA (Analysis of Variance) testing and the mean values were separated by the least significant difference (LSD) using MS Excel and R software (Table 3).

Table 1. Composition of callus induction media are as follows.

\begin{tabular}{ccl}
\hline $\begin{array}{c}\text { Callus } \\
\text { induction } \\
\text { media }\end{array}$ & $\begin{array}{c}\text { Basal } \\
\text { media }\end{array}$ & Media combination \\
\hline $\mathrm{C}_{1}$ & $\mathrm{MS}$ & $\mathrm{MS}+2 \mathrm{mg} / 12,4-\mathrm{D}$ \\
$\mathrm{C}_{2}$ & $\mathrm{MS}$ & $\mathrm{MS}+2 \mathrm{mg} / 12,4-\mathrm{D}+0.5 \mathrm{mg} / 1$ kinetin \\
$\mathrm{C}_{3}$ & $\mathrm{~N} 6$ & $\mathrm{~N}_{6}+2 \mathrm{mg} / 12,4-\mathrm{D}$ \\
$\mathrm{C}_{4}$ & $\mathrm{~N} 6$ & $\mathrm{~N}_{6}+2 \mathrm{mg} / 12,4-\mathrm{D}+0.5 \mathrm{mg} / 1$ kinetin \\
\hline
\end{tabular}

Table 2. Four hormonal combinations in regeneration media are as follows.

\begin{tabular}{|c|c|c|}
\hline $\begin{array}{l}\text { Regeneration } \\
\text { media }\end{array}$ & $\begin{array}{l}\text { Basal } \\
\text { media }\end{array}$ & Hormone combination \\
\hline $\mathrm{R}_{1}$ & MS & $\begin{array}{l}2 \mathrm{mg} / \mathrm{ml} \mathrm{BAP}+1 \mathrm{mg} / \mathrm{ml} \text { kinetin }+1 \\
\mathrm{mg} / \mathrm{ml} \mathrm{NAA}\end{array}$ \\
\hline $\mathrm{R}_{2}$ & MS & $\begin{array}{l}4 \mathrm{mg} / \mathrm{ml} \mathrm{BAP}+1.2 \mathrm{mg} / \mathrm{ml} \\
\text { kinetin+0.5 mg/ml NAA }\end{array}$ \\
\hline $\mathrm{R}_{3}$ & MS & $\begin{array}{l}1 \mathrm{mg} / \mathrm{ml} \mathrm{BAP}+1 \mathrm{mg} / \mathrm{ml} \\
\text { Kinetin+1mg/ml NAA }\end{array}$ \\
\hline $\mathrm{R}_{4}$ & MS & $\begin{array}{l}2 \mathrm{mg} / \mathrm{ml} \mathrm{kinetin}+1 \mathrm{mg} / \mathrm{ml} \\
\mathrm{NAA}+300 \mathrm{mg} \text { casein hydrolysate }\end{array}$ \\
\hline
\end{tabular}

Table 3. Analysis of variance (ANOVA) for callus induction and size of the calli.

\begin{tabular}{|c|c|c|c|}
\hline \multirow{2}{*}{$\begin{array}{c}\text { Source of } \\
\text { variation (SV) }\end{array}$} & \multirow{2}{*}{$\mathrm{DF}$} & \multicolumn{2}{|c|}{ Mean sum of square (MS) } \\
\hline & & Calli induction & Size of calli \\
\hline Variety (V) & 2 & $1281.60^{* * *}$ & $0.05^{* *}$ \\
\hline $\begin{array}{c}\text { Calli } \\
\text { induction } \\
\text { media }(\mathrm{C})\end{array}$ & 3 & $3041.60^{* * *}$ & 0.02 \\
\hline $\mathrm{C}: \mathrm{V}$ & 6 & $561.03^{* * *}$ & 0.01 \\
\hline Residuals & 24 & 56.86 & 0.01 \\
\hline
\end{tabular}

\section{RESULTS AND DISCUSSION}

\section{Callus initiation in varieties}

The highest callus induction $(52.17 \%)$ was found in BRRI dhan86 followed by $(43.50 \%)$ BRRI dhan 87 and the lowest $(31.58 \%)$ was in BRRI dhan89 (Table 4). Thus, BRRI dhan86 showed comparatively better potential in callus induction compared to other varieties. At the beginning, scutellum callus was compact almost in all varieties but turned into friable after two weeks of culture. Calli of BRRI dhan86 were bright yellowish, look most healthy compared to other varieties (Fig. 1a-f).

BRRI dhan87 performed better in media $\mathrm{C}_{2}$ followed by $\mathrm{C}_{4}$ and $\mathrm{C}_{3}$. The results found of this study are in agreement with the findings of other researchers largely depending on the use of harmonious combinations of nutritional constituents and growth regulators. There are many factors influence callus induction in rice like genotype potentiality, $\mathrm{PH}^{\mathrm{H}}$ of the media, plant growth regulators (PGRs) supplement, solidification of culture medium, light intensity etc. Joyia et al., (2012). Yaqoob et al., (2016) reported that mature dehusked rice seeds

Table 4. Interaction between the genotypes and media for callus induction of three rice genotypes.

\begin{tabular}{|c|c|c|c|c|c|}
\hline \multirow{2}{*}{$\begin{array}{c}\text { Calli } \\
\text { induction } \\
\text { media } \rightarrow \\
\text { Varieties } \downarrow\end{array}$} & \multicolumn{2}{|c|}{ MS } & \multicolumn{2}{|c|}{$\mathrm{N}_{6}$} & \multirow{2}{*}{$\begin{array}{l}\text { Mean of } \\
\text { varieties }\end{array}$} \\
\hline & $\mathrm{C}_{1}$ & $\mathrm{C}_{2}$ & $\mathrm{C}_{3}$ & $\mathrm{C}_{4}$ & \\
\hline $\begin{array}{l}\text { BRRI } \\
\text { dhan86 }\end{array}$ & $83.00 \mathrm{~d}$ & $70.67 \mathrm{~cd}$ & $26.00 \mathrm{a}$ & $29.00 \mathrm{ab}$ & 52.17A \\
\hline $\begin{array}{c}\text { BRRI } \\
\text { dhan87 }\end{array}$ & $49.67 \mathrm{bc}$ & $71.00 \mathrm{~cd}$ & $24.33 a$ & $29.00 \mathrm{ab}$ & $43.50 \mathrm{~B}$ \\
\hline $\begin{array}{c}\text { BRRI } \\
\text { dhan89 }\end{array}$ & $45.67 \mathrm{ab}$ & $29.67 \mathrm{ab}$ & $24.67 \mathrm{a}$ & $26.33 a$ & $31.58 \mathrm{C}$ \\
\hline $\begin{array}{c}\text { Calli } \\
\text { induction } \\
\text { media mean }\end{array}$ & $59.44 \mathrm{~A}$ & $57.11 \mathrm{~A}$ & 28.11B & $25.00 \mathrm{~B}$ & - \\
\hline \multicolumn{6}{|c|}{$\begin{array}{l}\text { *In interaction means in both row and column indicate a } \\
\text { common small letter(s) are not different significantly. } \\
(\mathrm{P} \leq 0.05) \\
\text { *In a row, calli induction media mean indicates a common } \\
\text { capital letter(s) are not different significantly. ( } \mathrm{P} \leq 0.05) \\
\text { *In a column mean of varieties indicate a common capital } \\
\text { letter(s) are not different significantly. }(\mathrm{P} \leq 0.05)\end{array}$} \\
\hline
\end{tabular}



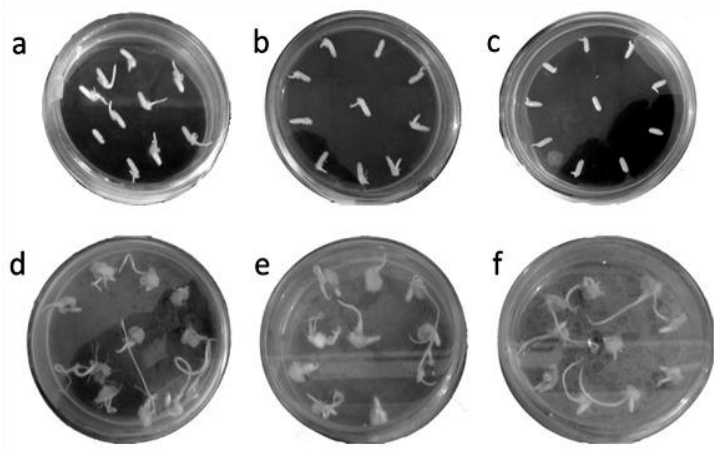

Fig. 1. Seed placement of BRRI dhan86 (a), BRRI dhan 87 (b) and BRRI dhan89 (c) and callus initiation of BRRI dhan86 (d), BRRI dhan87 (e) and BRRI dhan89 (f) into media.

were good for callus induction because of callus initiated from scutellum of mature rice seeds have high embryogenic potentiality. Amer et al., (2016) and Ahmad et al., (2015) also reported that embryogenic calli have high regeneration capacity and excellent material for the transformation of rice by using Agrobacterium.

\section{Effect of medium on callusing}

From this study, it was found that the varieties, media compositions and their interactions significantly affected on callus induction at the $5 \%$ level of significance. Among the media composition, $C_{1}$ and $C_{2}$ were significantly higher than $C_{3}$ and $C_{4}$ media for effective callus induction. The rate of callus induction was similar in $C_{3}$ and $C_{4}$ media (Table 4). The rate of callus induction was also similar in $C_{1}$ and $C_{2}$ media, but calli obtained from $C_{1}$ medium were quite good in texture and friable in nature than that of $\mathrm{C}_{2}$ medium. MS and $\mathrm{N}_{6}$ are the most commonly used basal media for calli induction and regeneration (Azizi et al., 2015). BRRI dhan86 in MS medium gave better callus induction as compared to $\mathrm{N}_{6}$ media, these findings were similar to the report by Islam et al., (2014) who indicated that variety was one of the major determinants in embryogenic callus induction. Kido et al.
(2015), Narciso et al. (2010) and Roy et al. (2015) also reported that embryogenic callus formation and plantlet regeneration were influenced by culture medium and variety.

The mean frequency of calli size over media (Table 5) showed that the variety BRRI dhan87 produced larger calli $(0.47 \%)$. Among the media composition we found, calli size on $C_{3}$ media were higher than $C_{1}, C_{2}$ and $C_{4}$ media. BRRI dhan87 produced larger size calli from $C_{3}(0.54 \%)$ and $C_{2}(0.51 \%)$ media and BRRI dhan89 produced lower size calli in $\mathrm{C}_{2}$ $(0.27 \%)$ than the other two varieties. Variations were observed among the three varieties but there was no significant differences.

The concentrations of the plant growth regulators also affect the callusing of the genotypes. In this study, 2, 4-D was used at the rate of $2 \mathrm{mg} / 1$. Previous studies also showed that callus could be induced better in $2 \mathrm{mg} / 1$ (Shahsavari et al., 2010). These results are confirmatory to the findings of the other researchers (Htwe et al., 2011). Thus present investigation revealed that both genotypes and media compositions and their interaction largely affected the callus.

Table 5. Interaction between the varieties and media for calli size of three rice varieties.

\begin{tabular}{|c|c|c|c|c|c|}
\hline \multirow{2}{*}{$\begin{array}{c}\text { Media } \rightarrow \\
\text { Varieties } \downarrow\end{array}$} & \multicolumn{2}{|c|}{ MS } & \multicolumn{2}{|c|}{$\mathrm{N}_{6}$} & \multirow{2}{*}{$\begin{array}{l}\text { Mean of } \\
\text { varieties }\end{array}$} \\
\hline & $\mathrm{C}_{1}$ & $\mathrm{C}_{2}$ & $\mathrm{C}_{3}$ & $\mathrm{C}_{4}$ & \\
\hline BRRI dhan86 & $0.45 a$ & $0.39 a$ & $0.41 \mathrm{a}$ & $0.33 a$ & $0.39 \mathrm{AB}$ \\
\hline BRRI dhan87 & $0.47 \mathrm{a}$ & $0.51 \mathrm{a}$ & $0.54 \mathrm{a}$ & $0.37 \mathrm{a}$ & $0.47 \mathrm{~A}$ \\
\hline BRRI dhan89 & $0.37 \mathrm{a}$ & $0.27 a$ & $0.41 \mathrm{a}$ & $0.31 \mathrm{a}$ & $0.34 \mathrm{~B}$ \\
\hline $\begin{array}{l}\text { Calli induction } \\
\text { media mean }\end{array}$ & $0.43 \mathrm{~A}$ & $0.39 \mathrm{~A}$ & $0.45 \mathrm{~A}$ & $0.34 \mathrm{~A}$ & - \\
\hline
\end{tabular}

*In interaction means in both row and column indicate a common small letter (s) are not different significantly. $(\mathrm{P} \leq 0.05)$

*In a row, calli induction media mean indicates a common capital letter (s) are not different significantly. ( $\mathrm{P} \leq 0.05)$

*In a column mean of varieties indicate a common capital letter(s) are not different significantly. ( $\mathrm{P} \leq 0.05)$ 


\section{Regeneration of calli and green plant}

In vitro plant regeneration was investigated on MS medium supplemented with different combinations of BAP, Kinetin, and NAA (Kaswan et al., 2012). Several factors, such as variety, developmental stage of cells in the explants, plant growth hormone composition in the medium, carbohydrates source, have been reported to improve the frequency of plantlet regeneration in rice (Muhammad et al., 2014). Plant regeneration was observed as early as three weeks and continued to occur up to four weeks after calluses were placed on regeneration media (Fig. 2a-e). Likewise callus proliferation, regenerative capacities varied considerably among rice genotypes. Table 4 shows the ANOVA results for the regeneration of calli and green plants. It was found that varieties were highly significant for regenerated calli induction and variety and regenerated media interaction showed highly significant differences for regenerated green plants.

The addition of day to the regeneration medium appeared to exert the least influence of all factors studied for plant regeneration frequency (Table 6). Nevertheless; day differentially affected subsequent plant regeneration of three varieties.
Mean frequency of regenerated calli induction over varieties (Table 7) showed that the variety BRRI dhan 86 produced maximum callus $(53.06 \%)$ which was not significantly higher than other varieties BRRI dhan87 $(26.43 \%)$ and BRRI dhan89 (26.32\%). Among the media composition, media $\mathrm{R}_{2}(45.74 \%)$ was found to be most effective for regeneration. Although other varieties performed better in media $R_{3}, R_{4}$ and $R_{1}$, the quality of regenerated calli were not as good as those induced in $R_{2}$.

Mean frequency of green plants over varieties (Table 8) showed that the variety BRRI dhan86 produced maximum green plants $(41.37 \%)$ which was not significantly different than the rest of the varieties BRRI dhan87 (32.71\%) and BRRI dhan89 (31.01\%). Among the media composition for producing green plant, $\mathrm{R}_{2}$ was the found highest $(47.34 \%)$ followed by $R_{3}(42.23 \%)$ which did not significantly differ from the other media $R_{1}$ and $R_{4}$. Although some varieties performed better in media $R_{3}, R_{4}$ and $R_{1}$, the quality of regenerated green plants was not as good as those induced in $R_{2}$. Given the highly significant genotype effect, the statistical analysis is shown separately for each of them (Table 8).

Table 6. Analysis of variance (ANOVA) for regeneration of calli induction and green plants.

\begin{tabular}{lccc}
\hline \multirow{2}{*}{ Sources of variation } & DF & \multicolumn{2}{c}{ Mean sum of square (MS) } \\
\cline { 3 - 4 } & & Regenerated calli (\%) & Green plants (\%) \\
\hline Variety (V) & 2 & $15174.00^{* * *}$ & 1513.50 \\
Calli induction media (C) & 3 & 128.00 & 3962.67 \\
Regeneration media (R) & 3 & 1860.33 & $5258.33^{* *}$ \\
V:R & 6 & 1480.17 & $9364.50^{* * *}$ \\
V: D & 2 & 2265.00 & 338.50 \\
C:R & 9 & 859.22 & 2184.33 \\
V:C:R & 12 & $1479.50^{* *}$ & 1856.67 \\
V: R: D & 9 & 742.78 & 1592.44 \\
Residuals & 144 & 767.58 & - \\
\hline
\end{tabular}

** and ${ }^{* * *}$ indicates significant at the $5 \%$ and the $1 \%$ level of significance respectively. 

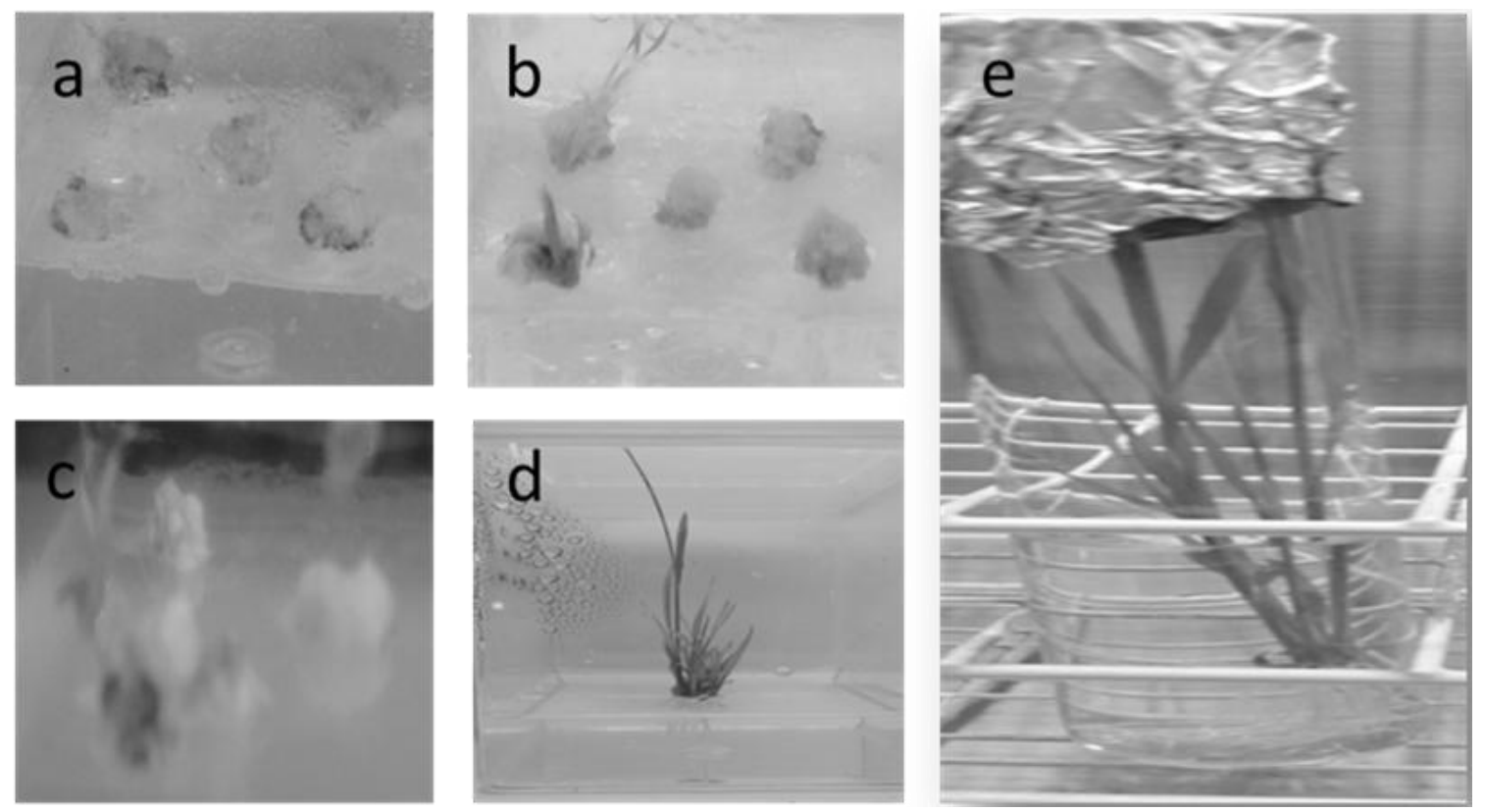

Fig. 2. Green bud initiation and induction of shoot (a-d), and established regenerated green plantlets of BRRI dhan86 (e).

Table 7. Interaction between the varieties and regeneration media for regenerated calli of three rice varieties.

\begin{tabular}{lccccc}
\hline $\begin{array}{l}\text { Regeneration media }(\mathrm{R}) \rightarrow \\
\text { Varieties (V) } \downarrow\end{array}$ & $\mathrm{R}_{1}$ & $\mathrm{R}_{2}$ & $\mathrm{R}_{3}$ & $\mathrm{R}_{4}$ & Mean of varieties \\
\hline BRRI dhan86 & $50.10 \mathrm{a}$ & $76.10 \mathrm{a}$ & $69.90 \mathrm{a}$ & $67.00 \mathrm{a}$ & $53.06 \mathrm{~A}$ \\
BRRI dhan87 & $40.90 \mathrm{a}$ & $38.10 \mathrm{a}$ & $40.40 \mathrm{a}$ & $37.30 \mathrm{a}$ & $26.43 \mathrm{~B}$ \\
BRRI dhan89 & $31.70 \mathrm{a}$ & $72.80 \mathrm{a}$ & $39.90 \mathrm{a}$ & $41.40 \mathrm{a}$ & $26.32 \mathrm{~B}$ \\
Regeneration mean & $29.26 \mathrm{~A}$ & $45.74 \mathrm{~A}$ & $38.64 \mathrm{~A}$ & $36.37 \mathrm{~A}$ & - \\
\hline
\end{tabular}

*In interaction means in both row and column indicate a common small letter (s) are not different significantly. ( $\mathrm{P} \leq 0.05)$

*In a row, calli induction media mean indicates a common capital letter (s) are not different significantly. (P $\leq 0.05)$

*In a column mean of varieties indicate a common capital letter (s) are not different significantly. (P $\leq 0.05)$

Table 8. Interaction between the varieties and regenerated media for green plants of three rice varieties three rice varieties.

\begin{tabular}{lccccc}
\hline $\begin{array}{l}\text { Plant regeneration media (R) } \rightarrow \\
\text { Varieties (V) } \downarrow\end{array}$ & $\mathrm{R}_{1}$ & $\mathrm{R}_{2}$ & $\mathrm{R}_{3}$ & $\mathrm{R}_{4}$ & $\begin{array}{c}\text { Mean of } \\
\text { varieties }\end{array}$ \\
\hline BRRI dhan86 & $31.20 \mathrm{a}$ & $69.00 \mathrm{a}$ & $82.70 \mathrm{a}$ & $58.60 \mathrm{a}$ & $41.37 \mathrm{~A}$ \\
BRRI dhan87 & $69.40 \mathrm{a}$ & $53.00 \mathrm{a}$ & $40.20 \mathrm{a}$ & $44.30 \mathrm{a}$ & $32.71 \mathrm{~A}$ \\
BRRI dhan89 & $38.80 \mathrm{a}$ & $104.20 \mathrm{a}$ & $71.00 \mathrm{a}$ & $30.10 \mathrm{a}$ & $31.01 \mathrm{~A}$ \\
Regeneration media mean & $27.55 \mathrm{~A}$ & $47.34 \mathrm{~A}$ & $42.23 \mathrm{~A}$ & $27.03 \mathrm{~A}$ & - \\
\hline
\end{tabular}

*In interaction means in both row and column indicate a common small letter (s) are not different significantly. (P $\leq 0.05)$

*In a row, calli induction media mean indicates a common capital letter (s) are not different significantly. (P $\leq 0.05)$

*In a column mean of varieties indicate a common capital letter (s) are not different significantly. (P $\leq 0.05)$ 
In a subsequent study, in comparison to the results presented here, higher regeneration frequency was observed in scutellar calli of all the three genotypes tested when dehusked seeds used as explants. Dehusked seeds proved to be better explants than matureembryos, possibly due to the involvement of endosperm factor(s) and some possible damage to the embryos during the process of embryo isolation from mature seeds. However, in the present study isolated embryos rather than dehusked seeds were used to eliminate any variation due to the involvement of endosperm. The results have demonstrated that the composition of basal media used for callus induction is not always optimum for plant regeneration as the nutritional requirements of the two phases of development may vary. Furthermore, this differential requirement was found to be variety dependent. Transfer of embryo-calli from callus induction medium to plant regeneration medium involved either a change of only the growth regulators or a change of both, growth regulators as well as the basal medium. Within a variety, significant differences affecting the regeneration parameters were observed between the two types of regeneration media (MS based regeneration medium and callus-induction basal medium based regeneration medium). In cultivar BRRI dhan86, variation was mainly due to regeneration media effect whereas in BRRI dhan87 and BRRI dhan89, callus induction medium affected the most. After transferring the calli into the regeneration medium, green spots became visible on the surface of the calli within 5-7 days were developed. MS medium supplemented with 4 $\mathrm{mg} / \mathrm{ml}$ BAP $+1.2 \mathrm{mg} / \mathrm{ml}$ kinetin $+0.5 \mathrm{mg} / \mathrm{ml}$ NAA was found the best in respect to percent regenerated planlet $(47.34 \%)$ as well as for the growth of plantlets in vitro. The addition of a small amount of Kinetin has been reported to improve embryogenic calli and shoot formation efficiency (Barbosa et al., 2014) in indica rice. Present finding agrees with the result of (Azizi et al., 2016 and Barman et al., 2016) where it was reported that kinetin was found to be more effective for plantlets regeneration compared with BAP (6benzylaminopurine). Combinations of Auxin and cytokinin along with the effect of basal salts played an important role in plant regeneration (Kumar et al., 2013).

The interaction effect of variety and medium on callus induction was not varied significantly. The highest callus induction was recorded in BRRI dhan86 (90.00\%) in $\mathrm{C}_{3}$ for callus induction and $R_{2}$ (Table 9). The lowest callus induction was observed in BRRI dhan87 (07.14\%) in $\mathrm{C}_{3}$ and $\mathrm{R}_{1}$.

However, higher frequencies of regeneration were associated with certain calli induction media (Table 9). Interestingly, for BRRI dhan86 was appeared to be an equal relationship between callus induction and highest plant regeneration capacity.

\section{CONCLUSIONS}

In summary, rice varieties showed significant divergence for their in vitro response to callus induction. The quality and frequency of callus induction and subsequent plant regeneration, however, ultimately depend on the composition of initial callus induction treatment. Therefore, selection of better responsive rice variety like BRRI dhan86 and medium designated as $C_{1}$ for callus induction as like as $R_{2}$ for regeneration would offer great promise for the induction of higher level of desired somaclones and quality of callus for various means of genetic transformation as well as in the selection of stress tolerant cultivar development program and other relevant studies for improving this world's staple food crop. 
Table 9. Interaction between the varieties and calli induction media on percent regenerated calli induction.

\begin{tabular}{|c|c|c|c|c|c|}
\hline \multirow{2}{*}{ Variety } & \multirow{2}{*}{ Callus induction media } & \multicolumn{4}{|c|}{ Regeneration media } \\
\hline & & $\mathrm{R}_{1}$ & $\mathrm{R}_{2}$ & $\mathrm{R}_{3}$ & $\mathrm{R}_{4}$ \\
\hline \multirow{4}{*}{ BRRI dhan86 } & $\mathrm{C}_{1}$ & $47.08 \mathrm{bc}$ & $61.07 \mathrm{bc}$ & $50.00 \mathrm{bc}$ & $75.00 \mathrm{bc}$ \\
\hline & $\mathrm{C}_{2}$ & $45.00 \mathrm{bc}$ & $52.92 \mathrm{bc}$ & $70.00 \mathrm{bc}$ & $47.14 \mathrm{bc}$ \\
\hline & $\mathrm{C}_{3}$ & $39.58 \mathrm{bc}$ & $90.00 \mathrm{c}$ & $45.83 \mathrm{bc}$ & $60.00 \mathrm{bc}$ \\
\hline & $\mathrm{C}_{4}$ & $8.33 b$ & $60.00 \mathrm{bc}$ & $74.29 \mathrm{bc}$ & $44.58 \mathrm{bc}$ \\
\hline \multirow{4}{*}{ BRRI dhan87 } & $\mathrm{C}_{1}$ & $22.5 b$ & $23.75 b c$ & $21.67 \mathrm{bc}$ & $25.00 \mathrm{bc}$ \\
\hline & $\mathrm{C}_{2}$ & $25.00 \mathrm{bc}$ & $23.75 b c$ & $46.67 \mathrm{bc}$ & $20.00 \mathrm{bc}$ \\
\hline & $\mathrm{C}_{3}$ & 07.14b & $23.33 b c$ & $20.00 \mathrm{~b}$ & $16.03 b c$ \\
\hline & $\mathrm{C}_{4}$ & $63.75 b c$ & $35.00 \mathrm{bc}$ & $30.00 \mathrm{bc}$ & $30.83 b c$ \\
\hline \multirow{4}{*}{ BRRI dhan89 } & $\mathrm{C}_{1}$ & $11.58 \mathrm{~b}$ & $0 \mathrm{a}$ & $0 \mathrm{a}$ & $0 a$ \\
\hline & $\mathrm{C}_{2}$ & $0 \mathrm{a}$ & $46.75 b c$ & $0 \mathrm{a}$ & $0 \mathrm{a}$ \\
\hline & $\mathrm{C}_{3}$ & $0 \mathrm{a}$ & $0 \mathrm{a}$ & $19.72 b$ & $0 \mathrm{a}$ \\
\hline & $\mathrm{C}_{4}$ & $0 \mathrm{a}$ & $0 \mathrm{a}$ & $0 \mathrm{a}$ & $20.30 \mathrm{~b}$ \\
\hline
\end{tabular}

Zero (0) represented by non-regenerated plants.

*In interaction means in both row and column indicate a common small letter(s) are not different significantly. (P $\leq 0.05)$

\section{REFERENCES}

Ahmad, N, N Fatima, I Ahmad and M Anis. 2015. Effect of PGRs in adventitious root culture in vitro: present scenario and future prospects. Rendiconti Lincei. 26(3):307-321.

Amer, A, S Eid and U Aly. 2016. Assessment of various factors for high efficiency transformation of Egyptian rice involving DREP2A gene. Int J Chem Tech Res. 9:201-213.

Azizi, P, M Y Rafii, M Mahmood, M M Hanafi, S N A Abdullah, R Abiri and M Sahebi. 2015. Highly efficient protocol for callogenesis, somagenesis and regeneration of indica rice plants. Comptes Rendus Biologies. 338(7):463-470.

Bandumula, N. 2018. Rice production in Asia: Key to global food security. Proceedings of the National Academy of Sciences, India Section B: Biol Sci, 88(4):1323-1328.

Barbosa, I D and A Chaparro-Giraldo. 2014. Optimization of an in vitro regeneration system for colombian indica rice varieties. Revista Colombiana de Biotecnología. 16(2):19-29.

Barman, H N, M E Hoque, R K Roy, P L Biswas, M A I Khan and M O Islam. 2016. Mature embryo-based in vitro regeneration of indica rice cultivars for high frequency plantlets production. Bangladesh Rice J. 20(2):81-87.

Benlioglu, B, D E Tuna, M A Birsin and A M Ozgen. 2015. Effect of growth regulators on tissue culture parameters in rice (Oryza sativa L.). Ekin J Crop Breed and Gen. 1(2):43-46.

Das, N K, H Hoque, M N Hasan and S H Prodhan. 2019. Effect of plant growth regulators and proline in efficient regeneration of recalcitrant indica rice (Oryza sativa L.). J Biol Sci. 19:290-299.

Din, A R J M, F I Ahmad, A Wagiran, A A Samad, Z Rahmat and M R Sarmidi. 2016. Improvement of efficient in vitro regeneration potential of mature callus induced from Malaysian upland rice seed (Oryza sativa cv. Panderas). Saudi J Biol Sci. 23(1):S69-S77.

Htwe, N N, M Maziah, H C Ling, F Q Zaman and A M Zain. 2011. Regeneration capacity of cell suspension culture in Malaysian rice genotypes under salinity stress. Asian J Biotech. 3(4):357-367.

Islam, M M, Z Y Roly, Y Lee and M Khalekuzzaman. 2014. In vitro propagation and genetic transformation system using immature embryo in elite rice (Oryza sativa L.) cultivars. Plant Breed and Biotech. 2(1):8896. 
Joyia, F A and M S Khan. 2012. Reproducible and expedient rice regeneration system using in vitro grown plants. African J Biotec. 11(1):138-144.

Kaswan, V, S Bhutani, V K Chowdhury and R K Jain. 2012. Morphogenetic competence and efficient plant regeneration in indica rice (Oryza sativa L.). J Cell and Tissue Res. 12(2):3219-3224.

Kido, N, R Yokoyama, T Yamamoto, J Furukawa, H Iwai, S Satoh and K Nishitani. 2015. The matrix polysaccharide $(1 ; 3,1 ; 4)-\beta$-D-glucan is involved in silicon-dependent strengthening of rice cell wall. Plant and Cell Physiol. 56(2):268-276.

Kumar, S S and K Ajinder. 2013. Genotype independent tissue culture base line for high regeneration of japonica and indica rice. Res J Biotech. 8(12):96-101.

Lim, Y Y, and K S Lai. 2017. Generation of transgenic rice expressing cyclotide precursor Oldenlandia affinis kalata B1 protein. J Anim Plant Sci. 27:680-684.

Muhammad, I, A Muhammad, Z Shaukat, A Sohaib, R Arshad, Z A Iqbal and G M Ali. 2014. Development of efficient regeneration system in different recalcitrant rice cultivars and expression analysis of putative transgenic plants. Int J Agri and Biol. 16(4):700-706.

Murashige, T and F Skoog. 1962. A revised medium for rapid growth and bio assays with tobacco tissue cultures. Physiologia plantarum, 15(3):473-497.

Narciso, J O and K Hattori. 2010. Genotypic differences in morphology and ultrastructures of callus derived from selected rice varieties. Philipp Sci Lett. 3:59-65.
Nitsch. 1969. https://phytotechlab.com>nitsch-nitschbasal-medium-with-vitamins.

Pawar, B, K A L E Prashant, J Bahurupe, A Jadhav, K A L E Anil and S Pawar. 2015. Proline and glutamine improve in vitro callus induction and subsequent shooting in rice. Rice Sci. 22(6):283-289.

Pazuki, A and M M Sohani. 2013. Phenotypic evaluation of scutellum-derived calluses in Indica rice cultivars. Acta agriculturae Slovenica. 101(2):239-247.

Roy, P, M Hasan, M G Rasul and M M Hossain. 2015. Seed culture of aromatic rice varieties under salt stress. American J Biol and Life Sci. 3(6):260.

Shahsavari, E. 2011. Impact of tryptophan and glutamine on the tissue culture of upland rice. Plant, Soil and Environ. 57(1):7-10.

Sripriya, R, C Parameswari and K Veluthambi. 2017. Enhancement of sheath blight tolerance in transgenic rice by combined expression of tobacco osmotin (ap24) and rice chitinase (chi11) genes. In Vitro Cellular and Developmental Biology-Plant. 53(1):12-21.

Vennapusa, A R, R S Vemanna, R R B H, K C Babitha, K Kiranmai, A Nareshkumar and C Sudhakar. 2015. An efficient callus induction and regeneration protocol for a drought tolerant rice indica genotype AC39020. J Plant Sci. 3(5):248.

Yaqoob, U, B Jan, T Kaul and I A Nawchoo. 2016. Tissue culture of rice: problems, progress and prospects. IJISET, 3(6):581-613. 